\title{
Guided Learning at Workstations about Drug Prevention with Low Achievers in Science Education
}

\author{
Heyne Thomas, ${ }^{1, *} \&$ Bogner Franz X. ${ }^{2}$ \\ ${ }^{1}$ Didactics of Biology, University of Würzburg, D-97074 Würzburg, Germany \\ ${ }^{2}$ Centre of Maths \& Science Education (Z-MNU), Institute of Biology Didactics, University of Bayreuth, D-95447 \\ Bayreuth, Germany \\ *Corresponding author: Didactics of Biology, University of Würzburg, Matthias-Lexer-Weg, Geb. 25, D-97074 \\ Würzburg, Germany Tel: 49-931-318-3789 E-mail: thomas.heyne@biozentrum.uni-wuerzburg.de
}

Received: October 1, $2012 \quad$ Accepted: November 7, $2012 \quad$ Online Published: November 15, 2012

doi:10.5430/wje.v2n6p1 URL: http://dx.doi.org/10.5430/wje.v2n6p1

The study was supported by the Bavarian State Ministry of Education as well as by the University of Bayreuth.

\begin{abstract}
Our study focussed on the cognitive achievement potential of low achieving eighth graders, dealing with drug prevention (cannabis). The learning process was guided by a teacher, leading this target group towards a modified learning at workstations which is seen as an appropriate approach for low achievers. We compared this specific open teaching approach with both, a conventional learning at workstations and a traditional teacher-centered approach. Two types of students of lowest stratification level in German school system participated, the regular level (R) and the higher level ones $(\mathrm{H})$. Thus, we compared students of two stratification sub-levels with regard to three teaching methods. Pre-, post- and retention tests were used to monitor knowledge achievement. The modified teaching approach achieved overall best results. $\mathrm{R}$ and $\mathrm{H}$ students reached similar levels of persistent knowledge in our specific approach. Thus, low achievers could reveal also high cognitive achievements in open learning environments. Consequences for school practice are discussed.
\end{abstract}

Keywords: Teaching Approaches; Learning at Workstations; Low Achiever; Constructivism; Drug Prevention

\section{Introduction}

\subsection{The Need for Using Open Learning Environments in Drug Prevention}

According to the German Federal Health Education Report (2004) 31\% of all teenagers had at some time consumed cannabis, $7 \%$ of which were 12 to 15 years old. These numbers are consistent with our study, where $8.1 \%$ low achievers had consumed cannabis once or more (Heyne \& Bogner, 2009). Thus, effective primary prevention measures are necessary and students desperately need specific knowledge in order to develop a negative attitude against illegal drugs. However, the question arises about the appropriate teaching method, because students often have a clearly defined standpoint on drugs. Thus, students should independently but effectively engage in drug-specific learning content.

\subsection{Learning at Workstations Realizes Constructivist Open Learning Environments}

Constructivism provides a launching pad for students individually and actively constructing new knowledge, always influenced by prior conceptions (Duit, Gropengießer, \& Kattmann, 2005; McRobbie \& Tobin, 1997). Therefore, the focus is on understanding information as well as improving self-determination and self-sufficiency levels, training through selected learning methods and in social competences as well (Cuban, 1983; Hasselhorn \& Gold, 2006). Open or situated learning environments provide situations favourable for constructivist approaches by opening teaching method, social form, learning atmosphere and material environment (Berck, 2001; Wallrabenstein, 2001). Synonyms of open learning environments would be student-oriented (Sturm \& Bogner, 2008), student-centered (Cuban, 1983) and learner-centered (Schuh, 2004). Workstations generally constitute open 
student-centered teaching methods (Bauer, 2003; Hepp, 1999) and allow working with self-instructional material at the individuals' pace (Schaal \& Bogner, 2005; Sturm \& Bogner, 2008). The teacher's role shifts towards being a supporter when students work autonomously and cooperatively in small groups (Randler \& Bogner, 2002). Students determine the time spent and the work pace at each station by themselves. Every student gets his/her own workbook, which enables him/her to apply the acquired knowledge pursuant to the situated learning. Any learning at workstations links learning effects and cooperative aspects inseparably. Cooperative learning is a form of classroom organisation. Students work in small groups to help each other when learning a subject matter (Slavin, 1989). Meta-analyses (Bowen, 2000; Johnson, Johnson \& Stanne, 2000; Lord, 2001; Slavin, 1980) confirmed positive effects with regard to learning success in cooperative learning groups. By reviewing 28 studies, Slavin (1980) summarised the higher efficiency of low-level learning objectives, such as acquisition of knowledge through cooperative learning approaches. Bowen (2000) defined as valuable variables interdependence, face-to-face interaction, individual accountability, interpersonal skills, for instance communicating effectively, and group processing. Our use of workstations followed this same philosophy.

\subsection{The Influence of Text Blindness on Cognitive Achievement in Student-Centered Learning Environments}

The Bavarian school system in Germany consists of three school types of different stratification levels. Low achiever find themselves in the lowest stratification-level called Hauptschule. In general, two stratification sub-levels of low achievers are distinguished above the $6^{\text {th }}$ grade: (a) regular level students (R); (b) higher level students $(H)$. For the latter ones, an average grading score in the main $6^{\text {th }}$ grade subjects is decisive for inclusion in the higher stratification. Consequently, R students are mainly very low achievers. However, the official syllabus of the lowest stratification level asks for student-centered approaches such as learning at workstations. In the practice, teachers reject this with the argument that workstations are not practicable due to their excessive demand on students. Bohl (2001), however, stated persistent deficiencies in the current preservice teacher education with regard to student-centered teaching methods. In this context, Mandl and Reinmann-Rothmeier (1999) pointed out that only high achievers really benefited from student-oriented approaches, because sufficient reading skills are a precondition for these approaches and a main problem for low achievers. Klicpera and Gasteiger-Klicpera (1993) or Juel (1998) levelled $15 \%$ of the weakest $8^{\text {th }}$ graders as average reading skills of a $2^{\text {nd }}$ grader, pointing to the tremendous degree of difference. The Program for International Student Assessment 2000 (Artelt et al., 2001) specifically assessed the reading competence of 15 -year-olds by monitoring cognitive basic skills and efficiencies in decoding (the ability to understand a sentence meaning) by detailing two important conditions of reading competence. A competence level two (out of five altogether) was specified as a minimum level for secondary schools. However, only $43 \%$ of the low achiever stratification in Germany reached this level and 25\% did not even meet the lowest level (Artelt et al., 2001; Baumert et al., 2002). Therefore, low achievers are unable to cope with constructive learning situations when teachers do not specifically instruct them and give serious attention in designing learning materials (Duit et al., 2005). Resnick, Wiliams, and Hall (1998) even stated that without instructions and support knowledge cannot be acquired.

\subsection{Feedback as Chance to Close Gaps in Knowledge and Understanding of Low Achievers}

Therefore, any learning material systematically and didactically needs an appropriate adaptation to selected requirement level. Additionally, multimedia representation and hands-on activities requirements needs taken to be into account by integrating different ways of thinking and learning styles (Bauer, 1997; Stohr-Hunt, 1996). We have assumed, therefore, that just for the subsample of $\mathrm{H}$ students reasonable results will occur when working at workstations without then needing further assistance, but not for $\mathrm{R}$ students. Thus, a rather passive and only sporadically supporting teacher's role at workstations would not support sufficient learning. We, therefore, suggested that individual groups after working through the learning materials, once again recapitulate the newly gained knowledge. Due to the fact that verbal summaries require thinking about and retained at about $70 \%$ in long-term memory (Bauer, 1997), we intended to close potential gaps in understanding by providing specific feedback. Walpuski (2006) described feedback as specifically enhancing factors for a learning success in cooperative learning environments. Stäudel, Franke-Braun, and Schmidt-Weigand (2007) used step-by-step learning aids to generate an issue-related communication for closing the gap in basic understanding already present in the groups. We asked students to write down open and not yet solved issues and so to represent them during the conversation with the researcher hoping that this would close gaps in the knowledge and understanding of $\mathrm{R}$ students. We called this modified approach as a guided learning at workstations.

\subsection{Instruction Groups}

Additionally, we compared a lecture given by the teacher to the conventional and modified guided learning at workstations, although this teaching method presents a very traditional teacher-centered approach (Aschersleben, 
1986). Knowledge may be transferred as abstract information from the teacher to the students (Kember \& Gow, 1994). We hypothesized that low achievers might not find be able to easily support such passive listening and watching. Our study specifically aimed at comparing the cognitive outcome of three contrasting teaching methods. The evaluation referred to all students in the respective teaching-approaches, but mainly to the sub-samples.

\subsection{Hypotheses}

We developed four hypotheses:

1) All students who will attend the modified guided learning at workstations will produce better results than those who participate in the other two instructional approaches.

2) The $\mathrm{R}$ group and the $\mathrm{H}$ group may achieve the same cognitive results due to the modified guided teaching approach.

3) The variation of the used teaching methods may not show an effect on cognitive achievement of $\mathrm{H}$ students.

4) R students may only have better cognitive outcomes by participating in the modified guided learning program compared to those $\mathrm{R}$ students who attend the other instructional approaches.

\section{Methodology}

\subsection{Sample}

The subjects of our study were 16 classes in Bavaria. They were low-achieving $8^{\text {th }}$ graders diversified in two sub-levels, a regular level one (R-class; $n=133$ of 7 classes) and a higher level one (H-class; $n=116$ of 6 classes). Their age ranged between 13 and 17 years $(M=13.9 ; S D=0.71)$.

\subsection{Quasi-experimental Design}

The study consisted of a quasi-experimental design (Table 1). In the substance-specific content only one instruction model was applied per class which followed either a conventional learning approach at workstations, labelled as group 1 (G1), a guided learning approach at workstations, labelled as group 2 (G2) or a traditional teacher-centered approach, labelled as group $3(\mathrm{G} 3)$. A control group $(n=52)$ served for test assessment and exclusion of other potential external influences (Lienert \& Raatz, 1998). In order to avoid a bias caused by the teacher as a person, which is known to correlate strongly with learning and achievement (Pintrich, Marx, \& Boyle, 1993), we decided to rely on one single researcher to provide all instructions. This researcher was previously not personally known to the students.

In addition to communicating specific drug abuse prevention knowledge, a necessary increase in the student's individual self-esteem and resistance self-efficacy was hypothesised as a further focus of our intervention. This substance-unspecific was divided into two interventions that were equally taught to all classes (Heyne \& Bogner, 2009).

Table 1: Quasi-experimental design of the study

Groups

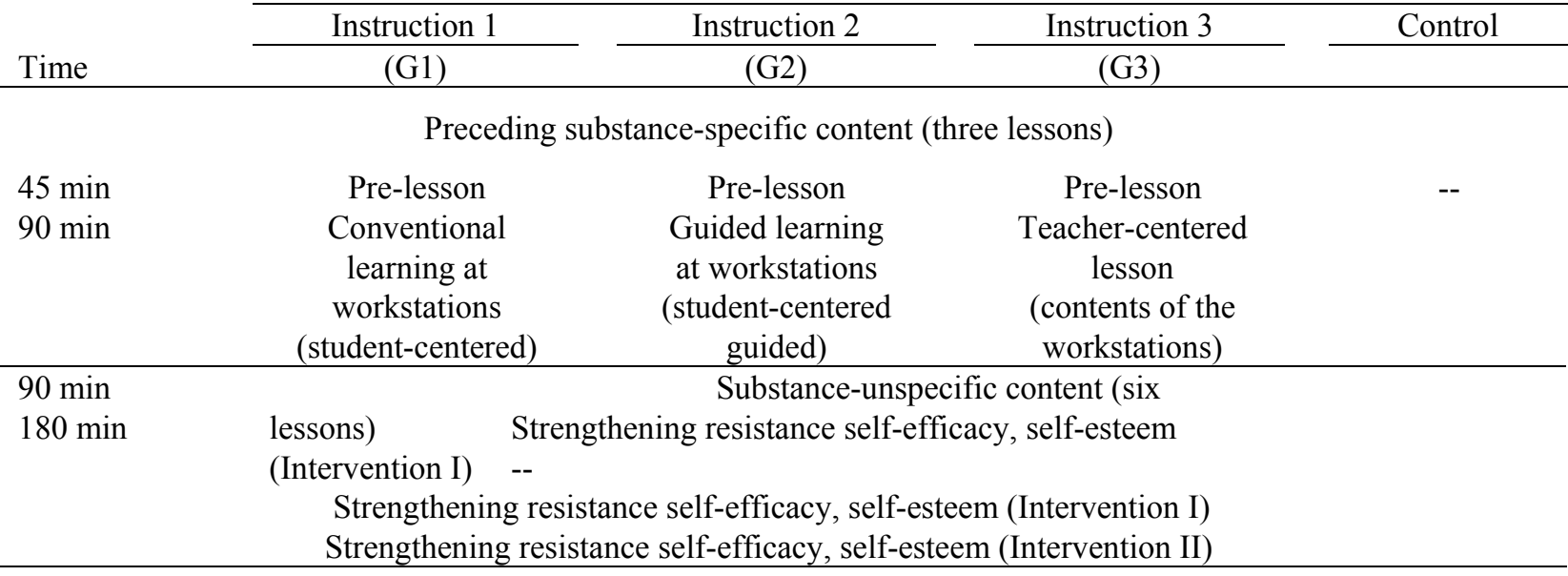


All of the classes except the control classes received a teacher-centered classroom lesson in all three instructional interventions (pre-lesson), dealing with the basic information on illegal drugs.

\subsection{Teaching Approaches and Independent Variables}

The following 90-minute period differed in its implementation in three treatment groups (Table 1). The drug cannabis was the major lesson subject (Appendix A). Thirteen classes were divided into three treatment groups.

\subsubsection{Instruction 1 - Conventional Learning at Workstations (G1)}

In instruction $1(n=72)$ students in small groups learned at eight workstations (Appendix A). The groups were assembled voluntarily. Each student received a workbook highlighting one chapter for each workstation. Before commencing, the students were given a solid introduction to the workbook program. Sturm and Bogner (2008) showed that this approach could enhance the cognitive outcome. At all workstations, the students had to read their work assignment together, complete the work by using the learning materials offered as well as to discuss and complete the respective tasks together in the workbook. After finishing the workstation session, every group compared its individual conclusion to an expert solution. The teacher's role was limited assisting and explaining functional or operational problems encounter only (Bauer, 2003). All workstations were provided as separate units. To prevent the faster working groups from disturbing the slower ones, an additional station was offered as well as special booklets about illegal drugs.

\subsubsection{Instruction 2 - Guided Learning at Workstations (G2)}

Instruction $2(n=93)$ followed the procedure for learning at workstations as described for the G1-group with the specific difference of the teacher role itself who now turned to being a real supporter. After completing the learning program at one of these workstations, the groups once again recapitulated the information gained with the researcher. Since it is necessary for these students to recall the learned for telling the researcher what they have learned, this requires these students to learn the material adequately. Additionally, students were asked to formulate two questions arising from the group work. Two firm guide-lines for question construction were given to the students that the questions should be either about difficulties in understanding the factual content or questions arising from the contents. The work of formulating questions should significantly promote effective communication between the groups to facilitate the comprehension of the facts. Finally, as outlined above from a common knowledge basis, the whole group discussed the contents and the formed questions with the researcher and got feedback. Feedback should be provided to demonstrate to students, what was achieved and what should or could have been achieved (Bauer, 1997). Thus, knowledge gaps were closed, coherent understanding was created.

\subsubsection{Instruction 3 - Teacher-Centered Lesson (G3)}

In instruction $3(n=84)$, the content of the workstations was taught by the teacher. The material was identical and sequentially taught by step-by-step instructions.

\subsection{Dependent Variable}

For the evaluation purposes, a specific cognitive achievement questionnaire was developed. After pilot testing of three classes 20 questions were given to all instruction groups concerning the gateway drug Cannabis. Four possible answers were presented to the students to every question. Only one answer could be marked. Questions were asked to each of the eight learning stations. The learning stations included experiments, multimedia information material and hands-on activities (Appendix A). Each instruction group responded three times to the identical knowledge test. To eliminate the potential for bias, the order of single questions and the order of the four possible multiple choice answers per question, respectively, were changed. Additionally, students were never aware of any testing schedule or of any repeated testing situation (Bogner, 1998). The pretest $\left(T_{1}\right)$ was conducted one week before the intervention. Immediately after participation in the respective teaching-methods, all students completed a posttest $\left(\mathrm{T}_{2}\right)$. Finally, six weeks after the post-test, the students completed a retention test $\left(\mathrm{T}_{3}\right)$ to determine the amount of persistent knowledge (Bogner, 1998). The pretest served to test previously existing knowledge about illegal drugs and to find out if there were any differences between $\mathrm{R}$ and $\mathrm{H}$ students and there were. Thus, sum scores could not be used in the comparison of R and H students for computing. Scharfenberg, Bogner, and Klautke (2007) created difference variables, called actual and persistent learning success to avoid this problem. These variables take into account the different base levels and were computed generally for illustrating our results. The control groups attended only the pre- and the retention test within the same six-week time-frame without being given any instructions on the topic of illegal drugs before or during the assessment. 


\subsection{Statistical Analysis}

SPSS 20 was used for statistical analysis. To conduct statistical computations of the multiple choice questions, correct answers were rated with one score, incorrect ones with none. After deleting 5 items reliability analysis revealed best data $\left(\alpha_{\text {pre }}=.45, \alpha_{\text {post }}=.63\right.$ and $\left.\alpha_{\text {retention }}=.60\right)$. Nevertheless, Lienert and Raatz (1998) discussed reliability analyses in knowledge tests always as difficult due to its ad-hoc-character. The range of item difficulty (i.e., percentage of correct answers, Bortz \& Döring, 2003) was normally distributed over all test schedules (Shapiro-Wilk tests, $p \geq .24$ in $\mathrm{T}_{1}, \mathrm{~T}_{2}$, and $\mathrm{T}_{3}$ ). Syllabus consistency provided appropriate content validity; all items followed the specific learning goals of our intervention, thus, providing criterion validity. Both, content and criterion validity was additionally confirmed by expert rating.

We used non-parametric tests for statistical evaluation, because sum scores of all three cognitive achievement tests were non-normally distributed. (Kolmogorov-Smirnov with Lilliefors Significance Correction, $p<.001$ in $\mathrm{T}_{1}$, $\mathrm{T}_{2}$, and $\mathrm{T}_{3}$ ). We applied the Wilcoxon-Test for pair-wise comparisons to determine the exact test date changes. H-test of Kruskal-Wallis was used for the comparison of our three independent samples. For non-normally distributed data, it substitutes ANOVA and ANCOVA (Zöfel, 2002, p.114). Chi-Square value is reported in addition when computing the Kruskal-Wallis test with SPSS 20. Finally, in case of significance, we employed the Mann-Whitney-U-Test for inter-group differences (Zöfel, 2002, pp. 111 \& 117).

\section{Results}

\subsection{Instruction Groups (Including $R$ and H Students in the Respective Teaching Approaches)}

The in group comparison (Wilcoxon-Test) of the three instruction groups revealed significant differences between the pre- $\left(T_{1}\right)$, post- $\left(T_{2}\right)$ and retention test $\left(T_{3}\right)$ (Table 2). Therefore, students in all teaching approaches learned and also forgot to a significant extent, irrespective of the teaching method used.

Table 2: In-group comparison of knowledge (Wilcoxon-Test, asympt.sig., 2-tailed)

\begin{tabular}{|c|c|c|c|c|c|c|c|}
\hline \multirow[b]{2}{*}{ Groups } & \multirow[b]{2}{*}{ (n) } & \multicolumn{2}{|c|}{$\mathrm{T}_{1}$ vs. $\mathrm{T}_{2}$} & \multicolumn{2}{|c|}{$\mathrm{T}_{1}$ vs. $\mathrm{T}_{3}$} & \multicolumn{2}{|c|}{$\mathrm{T}_{2}$ vs. $\mathrm{T}_{3}$} \\
\hline & & $Z$ & $p$ & $Z$ & $p$ & $Z$ & $p$ \\
\hline $\mathrm{G} 1^{a}$ & (72) & -7.277 & $<.001$ & -6.237 & $<.001$ & -5.746 & $<.001$ \\
\hline $\mathrm{G} 2^{b}$ & (93) & -8.389 & $<.001$ & -7.849 & $<.001$ & -7.731 & $<.001$ \\
\hline $\mathrm{G} 3^{c}$ & (84) & -7.932 & $<.001$ & -7.179 & $<.001$ & -6.615 & $<.001$ \\
\hline
\end{tabular}

${ }^{a}$ Student-centered. ${ }^{b}$ Student-centered guided. ${ }^{c}$ Teacher-centered.

G1 (student-centered), G2 (student-centered guided) and G3 (teacher-centered) provided similar pre-knowledge levels (Kruskal-Wallis-Test, Chi-Square (T-1) $_{1}=0.64 ; d f=2 ; p=.728$ ). Post- and retention test, however, differed

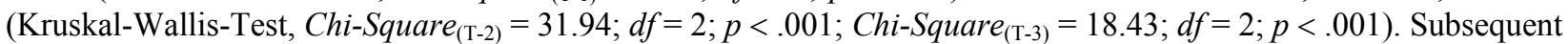
pair-wise analyses of the three instruction groups (Mann-Whitney-U-Test) identified significantly higher achievement scores for student-centered guided lessons (G2) in post- and retention tests compared to G1 (student-centered) and G3 (teacher-centered). G1 (student-centered) and G3 (teacher-centered) provided similar short-term- and long-term learning results as well. Consequently, the guided station-learning clearly caused a difference among all instruction groups, producing the best cognitive achievement results (Figure 1; Table 3; Appendix B). 


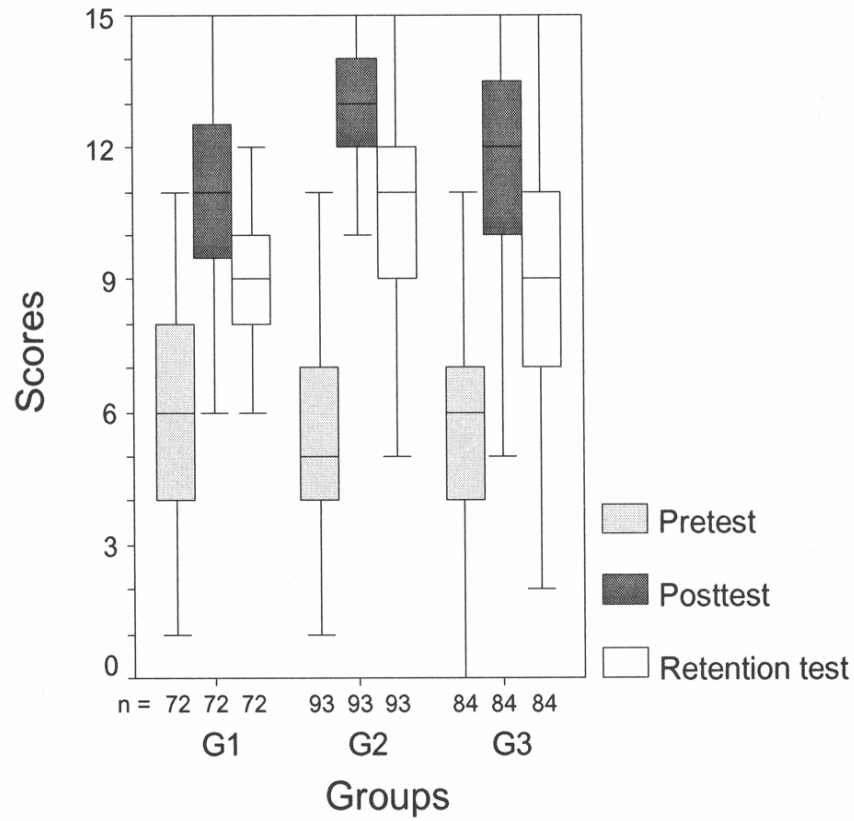

Figure 1: Changes in over-all knowledge scores in the three instruction groups over all test schedules;

$$
\text { G1 = student-centered; G2 = student-centered guided; G3 = teacher-centered }
$$

Table 3: Between-group comparison of knowledge in the post- and retention test (Mann-Whitney-U-Test)

\begin{tabular}{|c|c|c|c|c|}
\hline \multirow[b]{3}{*}{ Test } & \multicolumn{4}{|c|}{ Groups } \\
\hline & \multicolumn{2}{|c|}{$\mathrm{G} 1^{a}$} & \multicolumn{2}{|c|}{$\mathrm{G}^{b}{ }^{b}$} \\
\hline & $\bar{Z}$ & $p$ & $Z$ & $p$ \\
\hline \multicolumn{5}{|c|}{ Posttest } \\
\hline G1 & - & - & -5.435 & $<.001$ \\
\hline $\mathrm{G} 3^{c}$ & -1.608 & .108 & -3.892 & $<.001$ \\
\hline \multicolumn{5}{|c|}{ Retention test } \\
\hline G1 & - & - & -3.736 & $<.001$ \\
\hline G3 & -0.256 & .798 & -3.598 & $<.001$ \\
\hline
\end{tabular}

${ }^{a}$ Student-centered. ${ }^{b}$ Student-centered guided. ${ }^{c}$ Teacher-centered.

Control group scores did not differ significantly at all (Wilcoxon-Test, $Z=-0.443 ; p=.568$ ). Thus, during the six-week period without instructions no influence was observed nor as well was there any effect of our knowledge questionnaire at the test scores.

\subsection{In Group Comparison of G2 (student-centered guided)}

$\mathrm{R}$ and $\mathrm{H}$ students provided different pre-knowledge levels (Mann-Whitney-U-Test, assympt. sig., 2-tailed; $Z=$ $-2,283 ; p=.022)$. Consequently we had to compute difference variables labeled actual and persistent learning success. No differences between R and $\mathrm{H}$ students were given in G2, neither in the actual (Mann-Whitney-U-Test, assympt. sig., 2-tailed; $Z=-0.559 ; p=.576$ ) nor in the persistent learning achievement (Mann-Whitney-U-Test, assympt. sig., 2-tailed; $Z=-1.158 ; p=.247$ ). Thus, the guided student-centered approach benefited $\mathrm{R}$ students equally although they had to compensate for a knowledge deficit based on the pretest scores (Appendix B).

\subsection{Between Group Comparison of H Students}

There were no differences between the $\mathrm{H}$ students in the pre-test (Kruskal-Wallis-Test, Chi-Square $_{(\mathrm{T}-1)}=1.368$; $d f=2 ; p=.504$ ), but in the $\mathrm{T}_{2-}$ and $\mathrm{T}_{3}$ schedule (Kruskal-Wallis-Test, Chi-Square $_{(\mathrm{T}-2)}=9.121 ; d f=2 ; p=.010$; Chi-Square $\left._{(\mathrm{T}-3)}=10.509 ; d f=2 ; p=.005\right)$. On grounds of clarity we computed difference variables furthermore. The 
comparison of $\mathrm{G} 2_{\mathrm{H}}$ (student-centered guided) and $\mathrm{G} 1_{\mathrm{H}}$ (student-centered) showed, that the $\mathrm{G} 2_{\mathrm{H}}$ students performed significant higher scores in the actual- and persistent learning success. In the comparison of $\mathrm{G} 2 \mathrm{H}$ (student-centered guided) and $\mathrm{G}_{\mathrm{H}}$ (teacher-centered) $\mathrm{H}$ students achieved equally in short-term and long-term learning in both teaching methods (Figure 2; Table 4; Appendix B).

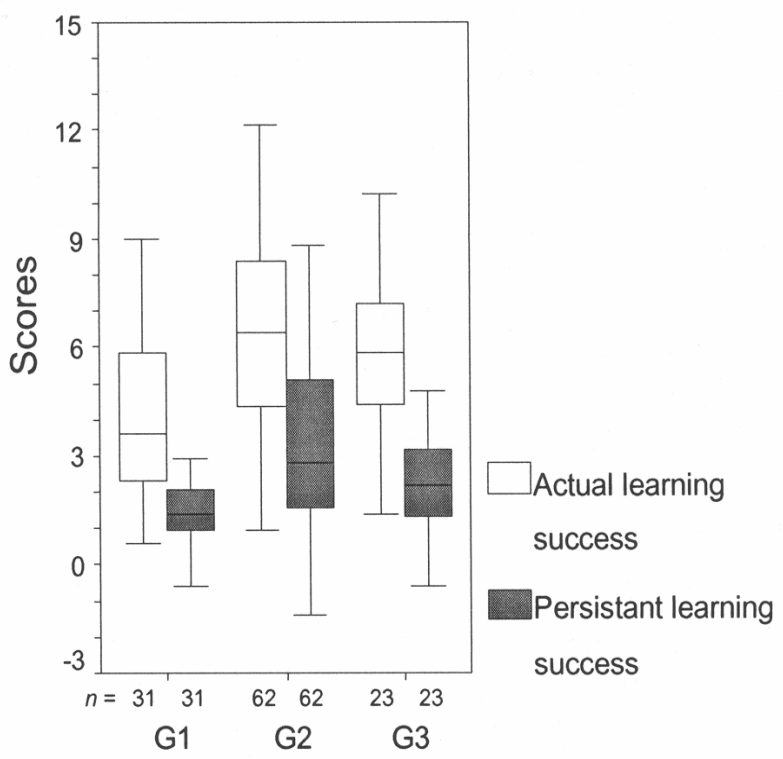

H-groups (low achiever)

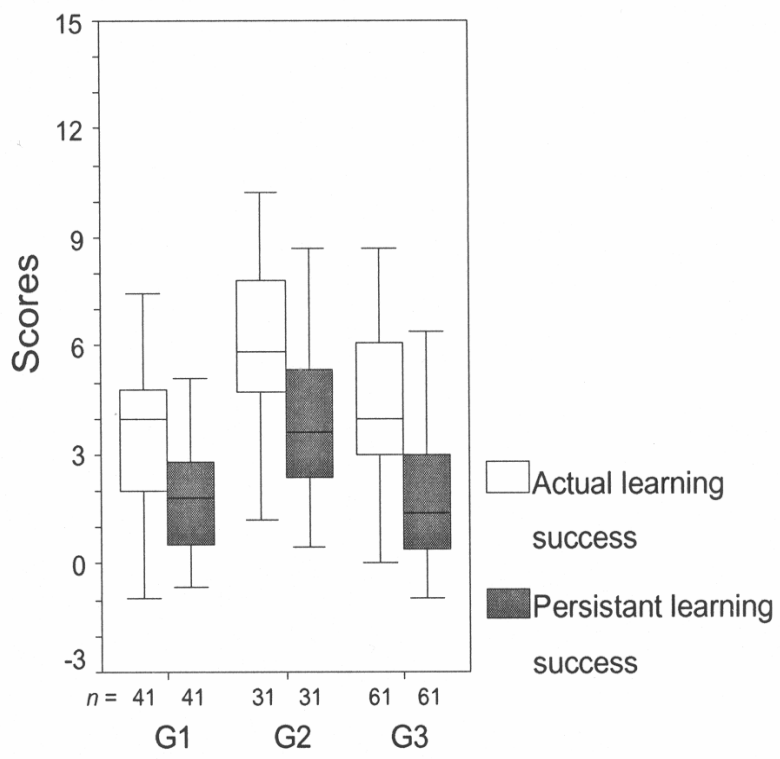

R-groups (low achiever)

Figure 2: Comparison of $\mathrm{R}$ - and $\mathrm{H}$-groups in the respective three instruction groups

G1 = student-centered; G2 = student-centered guided; G3 = teacher-centered

Table 4: Data of comparison of R and H groups in the respective three treatments (Mann-Whitney-U-Test)

\begin{tabular}{|c|c|c|c|c|}
\hline & \multicolumn{4}{|c|}{ Groups } \\
\hline & \multicolumn{2}{|c|}{ G1 } & \multicolumn{2}{|c|}{$\mathrm{G} 2^{b / e}$} \\
\hline & $Z$ & $p$ & $Z$ & $p$ \\
\hline \multicolumn{5}{|c|}{ Actual learning success } \\
\hline \multicolumn{5}{|c|}{ R-group } \\
\hline $\mathrm{G} 1^{a}$ & - & - & -4.000 & $<.001$ \\
\hline $\mathrm{G} 3^{c}$ & -1.072 & .284 & -3.405 & .001 \\
\hline \multicolumn{5}{|c|}{ H-group } \\
\hline $\mathrm{G} 1^{d}$ & - & - & -3.943 & $<.001$ \\
\hline $\mathrm{G} 3^{f}$ & -2.547 & .011 & -1.010 & .313 \\
\hline \multicolumn{5}{|c|}{ Persistent learning success } \\
\hline \multicolumn{5}{|c|}{ R-group } \\
\hline G1 & - & - & -3.425 & .001 \\
\hline G3 & -0.290 & .772 & -3.666 & $<.001$ \\
\hline \multicolumn{5}{|c|}{ H-group } \\
\hline G1 & - & - & -3.250 & .001 \\
\hline G3 & -1.900 & .057 & -1.430 & .153 \\
\hline
\end{tabular}




\section{Between Group Comparison of R Students}

There were also no differences between the $\mathrm{R}$ students in the pretest (Kruskal-Wallis-Test, Chi-Square (T-1) $=$ 1.368; $d f=2 ; p=.504$ ), changes occurred in the $\mathrm{T}_{2}$ and $\mathrm{T}_{3}$ schedule (Kruskal-Wallis-Test, Chi-Square $(\mathrm{T}-2)=9.121$; $d f=2 ; p=.010 ;$ Kruskal-Wallis-Test, Chi-Square $(\mathrm{T}-3)=10.509 ; d f=2 ; p=.005)$. The comparison of $\mathrm{G} 2{ }_{\mathrm{R}}$ (student-centered guided) and $\mathrm{G} 1_{\mathrm{R}}$ (student-centered) revealed similar results to the respective $\mathrm{H}$ instruction groups. $\mathrm{G} 2_{\mathrm{R}}$ students also achieved significant higher scores in the actual and persistent learning success compared to the $\mathrm{G}_{\mathrm{R}}$ students. Nevertheless, differences appeared to respective H-instruction groups in the comparison between $\mathrm{G} 2_{\mathrm{R}}$ (student-centered guided) and $\mathrm{G} 3_{\mathrm{R}}$ (teacher-centered). $\mathrm{G} 2_{\mathrm{R}}$ students achieved significant higher scores in the actual and persistent learning success compared to the $\mathrm{G}_{\mathrm{R}}$ students. (Figure 2; Table 4; Appendix B).

\subsection{Main Findings of the Study}

1) Altogether the modified guided student-centered approach (G2) produced a better cognitive outcome compared to the other two instructional approaches.

2) Within the modified guided student-entered approach (G2), R and $\mathrm{H}$ students achieved similarly despite the fact that $\mathrm{R}$ students showed a lower pre-knowledge.

3) No differences in cognitive achievement of $\mathrm{H}$ students existed between the guided student-centered (G2) and teacher-centered (G3) approach.

4) R-students revealed significant better short- and long-term results in the modified student-entered approach (G2) than in the other instructions.

\section{Discussion}

\subsection{Low Achievers and Open Learning Environments do not exclude Themselves}

Altogether, the students benefited more from the modified guided station learning approach compared to both of the other instructional methods. Schaal and Bogner (2005) as well as Sturm and Bogner (2008) reported that high achiever revealed significantly higher knowledge in a teacher-centered approach compared to a student-centered approach. This as a result contributed to certain didactic methodical mistakes within the student-centered workstations. For instance, a high number of workstations may contribute to a cognitive overload in the individual work assignment. This maybe became of reason in the simple desire to maximise spare time by completing a workstation activity faster. Finally Randler and Bogner (2006) found a result in a bird identification skill unit by higher short-term and long-term cognitive achievement scores for a student-centered approach when the learning material had been drastically reduced. We eliminated the potential trouble caused by specifically adapting the instruction materials and prior pilot-testing. Nevertheless, we considered these measures in the conventional student-centered approach as insufficient even for R students and influenced, in addition, especially the group work phases in the modified guided learning program. Finally, students significantly benefited more from our modified guided student-centered approach compared to the conventional approach. The comparison of both approaches confirmed this result for $\mathrm{R}$ and $\mathrm{H}$ students. Thus, the additional supporting measures in the group work phases were essential to the learning success. We obtained face-to-face interactions and effective, issue-related communication, as Bowen (2000) as well as Stäudel et al. (2007) have postulated, by alternating exactly defined teacher-student conversation with influenced group work phases, because some studies refer to the distracting effect of detailed questions or explanations of the teacher during group work phases (Walpuski, 2006). The success of guided learning at workstations can be explained twice. First, in the sector of group work, where within the peers sensitive contents were discussed in order to prepare themselves for the afterwards conversation with the teacher. Thus, many inherent fundamental problems were maybe already solved before conversing with the teacher. This collective knowledge and comprehension basis led to the following phase where, second, the group as a whole discussed with the researcher identifying still existing understanding-gaps by recapitulating again worked-out contents they remembered. Thus, students developed questions and incorporated them into a more general discussion. We, thereby, obviously obtained a precisely tailored connection of a learning process with an individually pre-existing knowledge. In this context, several studies have already confirmed the efficiency of the improvement to cooperative learning environments by the learning aids offered (Walpuski, 2006). This author showed that intermediate results that were ensured by questions to the teacher lead to significantly better results, too. To repeat, a high learning success results from a consistent closing of understanding-gaps through issue-relevant communication. What remains open is which part of positive learning effect refers to cooperative group- or teacher - student conversation. 
The efficiency of guided learning at workstations was confirmed in the between-group comparison of $\mathrm{R}$ and $\mathrm{H}$ students once again. In spite of a lower preknowledge of $\mathrm{R}$ students, they reached similar levels of actual and persistent learning success compared to $\mathrm{H}$ students. Appropriate learning aids obviously are able to tap the full potential to deepen a sufficient cognitive process (Stäudel et al., 2007). Therefore R students may compensate for the potential inhibitors to their learning, such as a low reading competence and consequential comprehension problems.

\subsection{Differentiated Consideration for Both Subsamples}

The cognitive achievement comparison of guided learning at workstations and the teacher-centered approach revealed quite similar levels in actual and persistent learning success for $\mathrm{H}$ students. However, the result of the persistent learning success in the teacher-centered approach seems disputable especially and should be evaluated with major instruction groups in a subsequent study. Already in 1968 Siedentop criticised a solely passive listening need during teacher's lectures, leading to a lack of individual demand and encouragement. Bauer (1997) rated only $20 \%$ of what was heard as ending up in long-term memory storage. R students of the teacher-centered approach confirmed these doubts impressively (Appendix B).

Against our third hypothesis $\mathrm{H}$ students did also not profit in the conventional student-centered approach compared to the guided learning approach (Appendix B). Low achievement results of students attending the student-centered program may be explained by a deficient usage of offered learning materials within the groups. Stäudel et al. (2007) reported a stepwise learning aid as significantly improving issue-related communication for team working when compared to simple information texts and showed consistently higher cognitive results, too. Thus, the subsequent completion of tasks in student workbook ensured that they completed the task properly. Hence, learning materials were mainly individually handled. Altogether well-conceived learning materials and applicationand problem-oriented workbooks do not guarantee successful cognitive learning in a conventional learning approach at workstations.

$\mathrm{R}$ students revealed low results in the student-centered and the teacher-centered approach as expected. It is an essential precondition that many information must be read in a student-centered environment. R students are often assigning a meaning to every word and show linguistic decoding deficiencies, for instance, by translating letters into words (Hasselhorn \& Gold, 2007). The meaning of many sentences was only very painstakingly decoded. Gräsel and Mandl (1993) indicated disorientation and excessive demand when cumulatively observing $\mathrm{R}$ classes. The low achievement results in the teacher's lecture approach for R students compared to the guided learning approach have to be explained by an overload in their role of passive listeners.

\section{Conclusion}

Guided learning at workstations constitutes a modified teaching method which also allows open, cooperative and successful learning especially for low achievers. In our drug abuse prevention program, the teaching content Cannabis could be delivered to the students with a high cognitive outcome and not influenced by the teacher using this teaching method - a basic requirement for forming an influenced and own opinion. Based on our empirical results, three aspects need specific consideration before the implementation of student-oriented learning environments when low achievers are the specific target. First, a pre-instruction has to ensure a common basis of knowledge. Second, due to a widespread occurrence of insufficiently developed reading skills, any learning materials need a specific adaptation by a teacher, constantly taking into consideration a proficiency level of the involved low achiever. Finally, low achievers always depend on a specific teacher's support. In spite of specifically adapted learning materials, developed contents and coherences separated phases of teacher intervention need to provide specific support.

\section{References}

Artelt, C., Baumert, J., Klieme, E., Neubrand, M., Prenzel, M., \& Schiefele, U. (2001). PISA 2000 Zusammenfassung zentraler Befunde [PISA 2000 - Summary of fundamental findings]. Berlin, Germany: Max-Planck-Institut für Bildungsforschung.

Aschersleben, R. (1986). Moderner Frontalunterricht. Neubegründung einer umstrittenen Unterrichtsmethode [Modern teacher-centered education. Come back of a controversial teaching-method]. Frankfurt a. M., Germany: Lang.

Bauer, R. (1997). Schülergerechtes Arbeiten in der Sekundarstufe I. Lernen an Stationen [Student-centered learning 
environments for secondary schools. Learning at workstations]. Berlin, Germany: Cornelsen Scriptor.

Bauer, R. (2003). Offenes Arbeiten in der Sekundarstufe I [Open learning environments for secondary schools]. Berlin, Germany: Cornelsen.

Baumert, J., Artelt, C., Klieme, E., Neubrand, M., Prenzel, M., \& Schiefele, U. (2002). PISA 2000. Die Länder der Bundesrepublik Deutschland im Vergleich [PISA 2000. The federal states of Germany in the comparison]. Opladen, Germany: Leske + Budrich.

Berck, K. H. (2001). Biologiedidaktik: Grundlagen und Methoden [Biology didactics: Basics and methods]. Wiebelsheim, Germany: Quelle \& Meyer.

Bogner, F. X. (1998). The Influence of Short-term Outdoor Ecology Education on Long- term Variables of Environmental Perspectives. Journal of Environmental Education, 29, 17-29.

Bohl, T. (2001). Wie verbreitet sind offene Unterrichtsformen? [How common are learning enviroments?]. Pädagogische Rundschau, 55, 217-287.

Bortz, J., \& Döring, N. (2003). Forschungsmethoden und Evaluation (3rd ed.) [Research methods and evaluation]. Berlin, Germany: Springer.

Bowen, C. W. (2000). A Quantitative Literature Review of Cooperative Learning Effects on High School and College Chemistry Achievement. Journal of Chemical Education, 77, 116-118. http://dx.doi.org/10.1021/ed077p116

Cuban, L. (1983). How did teacher teach, 1890-1980. Theory into Practice, 22, 160-165. http://dx.doi.org/10.1080/00405848309543056

Duit, R., Gropengießer, H., \& Kattmann, U. (2005). Towards science education research that is relevant for improving practice: The model of educational reconstruction. In H. Fischer (Ed.), Developing Standards in Research on Science Education (pp. 1-9). London: Taylor \& Francis.

German Federal Centre of Health Education (2004). Die Drogenaffinität Jugendlicher in der Bundesrepublik Deutschland. Eine Wiederholungsbefragung der BZgA [The drug affinity of youngsters in Germany. A recurringsurvey of the $B Z g A]$. Köln, Germany: Bundeszentrale für gesundheitliche Aufklärung (BZgA).

Gräsel, C., \& Mandl, H. (1993). Förderung des Erwerbs diagnostischer Strategien in fallbasierten Lernumgebungen [Supporting the acquirement of diagnostic strategies in learning enviroments]. Unterrichtswissenschaft, 21, 355-369.

Hasselhorn, M., \& Gold, A. (2006). Pädagogische Psychologie. Erfolgreiches Lernen und Lehren [Educational psychology. Successful learning and teaching]. Stuttgart, Germany: W. Kohlhammer.

Hepp, R. (1999). Lernen an Stationen im Physikunterricht [Learning at workstations in Physics]. Unterricht Physik, 10, 4-14.

Heyne, T., \& Bogner, F. X. (2009). Strengthening resistance self-efficacy: Influence of teaching approaches and gender on different consumption groups. Journal of Drug Education, 39, 439-457. http://dx.doi.org/10.2190/DE.39.4.f

Johnson, D. W., Johnson, R. T., \& Stanne, M. B. (2000). Cooperative Learning Methods: A Meta-Analysis. Retrieved on September 17, 2012 from http://www.tablelearning.com/uploads/File/EXHIBIT-B.pdf

Juel, C. (1988). Learning to read and write. A longitudinal study of 54 children from first through fourth grades. Journal of Educational Psychology, 80, 437-447. http://dx.doi.org/10.1037/0022-0663.80.4.437

Kember, D., \& Gow, L. (1994). Orientations to teaching and their effect on the quality of student learning. Journal of Higher Education, 65, 58-74.

Klicpera, C., \& Gasteiger-Klicpera, B. (1993). Lesen und Schreiben - Entwicklung und Schwierigkeiten [Reading and writing - Development and difficulties ]. Bern: Huber.

Lienert, G.A., \& Raatz, U. (1998). Testaufbau und Testanalyse [Test construction and test analysis]. Weinheim, Germany: Psychologie.

Lord, T. R. (2001). 101 Reasons for Using Cooperative Learning in Biology Teaching. The American Biology Teacher, 63, 30-38. http://dx.doi.org/10.1662/0002-7685(2001)063[0030:RFUCLI]2.0.CO;2

Mandl, H., \& Reinmann-Rothmeier, G. (1999). Unterrichten und Lernumgebungen gestalten [Teaching and creating 
learning enviroments]. In B. Weidenmann, \& A. Krapp (Eds.), Pädagogische Psychologie [Educational psychology] (pp. 625-636). Weinheim, Germany: Beltz.

McRobbie, C., \& Tobin, K. (1997). A social constructivist perspective on learning environments. International Journal of Science Education, 19, 193-208. http://dx.doi.org/10.1080/0950069970190205

Pintrich, P. R., Marx, R. W., \& Boyle, R. A. (1993). Beyond cold conceptual change. The role of motivational beliefs and classroom contextual factors in the process of conceptual change. Review of Educational Research, 63, 167-199. http://dx.doi.org/10.3102/00346543063002167

Randler, C., \& Bogner, F. X. (2002). Comparing methods of instruction using bird species identification skills as indicators. Educational Research, 36, 181-188. http://dx.doi.org/10.1080/00219266.2002.9655830

Randler, C., \& Bogner, F. X. (2006). Cognitive achievement in identification skills. Journal of Biological Education, 40, 1-5. http://dx.doi.org/10.1080/00219266.2006.9656038

Resnick, L. B., Wiliams, S. M., \& Hall, M. (1998). Learning organizations for sustainable education reform. Daedalus, 127, 89-118.

Schaal, S., \& Bogner, F. X. (2005). Human visual perception - learning at workstations. Journal of Biological Education, 40, 32-37. http://dx.doi.org/10.1080/00219266.2005.9656006

Scharfenberg, F. J., Bogner, F. X., \& Klautke, S. (2007). Learning in a Gene Technology Laboratory with Educational Focus. Biochemistry and Molecular Biology Education, 35, 28-39. http://dx.doi.org/10.1002/bmb.1

Schuh, K. L. (2004). Learner-centered principles in teacher-centered practices? Teaching and Teacher Education, 20 , 833-846. http://dx.doi.org/10.1016/j.tate.2004.09.008

Siedentop, W. (1968). Methodik und Didaktik des Biologieunterrichtes [Methodology and didactics in Biology]. Heidelberg, Germany: Quelle \& Meyer.

Slavin, R. E. (1980). Cooperative learning. Review of Educational Research, 50, 315-342. http://dx.doi.org/10.3102/00346543050002315

Slavin, R. E. (1989). Cooperative learning and student achievement. In R. E. Slavin (Ed.). School and classroom organization (pp. 129-156). Hillsdale, NJ: Erlbaum.

Stäudel, L., Franke-Braun, G., \& Schmidt-Weigand, F. (2007). Komplexität erhalten - auch in heterogenen Lerngruppen: Aufgaben mit gestuften Lernhilfen [Conserving complexity - also in heterogeneous learning groups: Tasks with step-by-step learning aids]. Chemkon - Forum für Unterricht und Didaktik, 14, 115-122.

Stohr-Hunt, P. M. (1996). An analysis of frequency of hands-on experience and science achievement. Journal of $\begin{array}{lllr}\text { Research in } \quad \text { Science } & \text { Teaching, } & \text { 100-109. }\end{array}$ http://dx.doi.org/10.1002/(SICI)1098-2736(199601)33:1<101::AID-TEA6>3.0.CO;2-Z

Sturm, H., \& Bogner, F. X. (2008). Student-oriented versus teacher-centered: The effect of learning at workstations about birds and bird flight on cognitive achievement and motivation. International Journal of Science Education, 30, 941-959. http://dx.doi.org/10.1080/09500690701313995

Wallrabenstein, W. (2001). Offene Schule- Offener Unterricht [Open learning environments]. Hamburg, Germany: Rowohlt.

Walpuski, M. (2006). Optimierung von experimenteller Kleingruppenarbeit durch Strukturierungshilfen und Feedback. Eine empirische Studie [Optimizing experimental learning in small groups by providing adequate aids and feedback. An empirical study]. Berlin, Germany: Logos.

Zöfel, P. (2002). Statistik verstehen. Ein Begleitbuch zur computergestützten Anwendung. [UnderstandingStatistics. An accompanying book for computer-supported utilization]. München, Germany: Adison-Wesley.

\section{Acknowledgment}

We appreciate the cooperation of teachers and students involved in this study as well as we are very thankful to F.-J. Scharfenberg and S.P. Tomkins for valuable discussions and reading the text. 


\section{Appendix A}

\begin{tabular}{|c|c|c|}
\hline Titles of workstations & Method & Focused outcome \\
\hline 1. What at all is cannabis? & Information text & $\begin{array}{l}\text { Cannabis as topic for marihuana, hashish } \\
\text { and species plant }\end{array}$ \\
\hline 2. Consumption and types of hashish & Information text & $\begin{array}{l}\text { Smoking utensiles: joint, shillum, water } \\
\text { pipe; } \\
\text { relationship between country of origin } \\
\text { and colour of hashish }\end{array}$ \\
\hline 3. Active agent, effect and verifiability & $\begin{array}{l}\text { Information text } \\
\text { Drug test: Drug Wipe }\end{array}$ & $\begin{array}{l}\text { THC and mode of action; } \\
\text { functionality of drug tests }\end{array}$ \\
\hline 4. Effects of hashish & $\begin{array}{l}\text { Audio text with hands-on } \\
\text { activities }\end{array}$ & $\begin{array}{l}\text { Health impacts, cognitive and } \\
\text { concentration disturbance }\end{array}$ \\
\hline 5. Hash jag when driving & Information text & $\begin{array}{l}\text { Effects on hearing, colour vision and } \\
\text { ability to estimate distances }\end{array}$ \\
\hline 6. Tunnel view & $\begin{array}{l}\text { Experiments with } \\
\text { per mille classes }\end{array}$ & Haziness and cramped range of vision \\
\hline 7. Limit and penalty (cannabis) & $\begin{array}{l}\text { Audio text with explanatory } \\
\text { graphics }\end{array}$ & $\begin{array}{l}\text { Limits of consumption, fines and driving } \\
\text { ban }\end{array}$ \\
\hline 8. Death of an innocent & Movie & $\begin{array}{l}\text { Discussion about guilt and innocence of a } \\
\text { drug-driver }\end{array}$ \\
\hline 9. Limit and penalty (alcohol) & $\begin{array}{l}\text { Information text with } \\
\text { explanatory graphics }\end{array}$ & $\begin{array}{l}\text { Limits of consumption, fines and driving } \\
\text { ban }\end{array}$ \\
\hline
\end{tabular}

Workstations, methods and the expected learning outcomes

(Learning station 9 is optional)

\section{Appendix B}

\begin{tabular}{|c|c|c|c|}
\hline \multirow[t]{2}{*}{ Groups } & \multicolumn{3}{|c|}{ Grouped Median $(25 / 75$ th $P)$} \\
\hline & $\mathrm{T}_{1}$ & $\mathrm{~T}_{2}$ & $\mathrm{~T}_{3}$ \\
\hline \multirow[t]{2}{*}{ G1 (student-centered) } & $5.9(2.7 / 9.0)$ & $11.2(9.3 / 11.9)$ & $9.0(7.7 / 10.2)$ \\
\hline & Actual learn & \multicolumn{2}{|c|}{ Persistent learning success } \\
\hline $\mathrm{R}_{\mathrm{G} 1 \text {-group }}$ & $3.9(1$. & \multicolumn{2}{|c|}{$1.8(1.2 / 4.0)$} \\
\hline $\mathrm{H}_{\mathrm{G} 1}$-group & $3.6(2$. & \multicolumn{2}{|c|}{$1.4(1.1 / 6.8)$} \\
\hline G2 (student-centered guided) & $5.4(2.6 / 8.8)$ & $13.2(12.0 / 13.8)$ & $10.5(8.9 / 11.3)$ \\
\hline $\mathrm{R}_{\mathrm{G} 2}$-group & $6.0(2$. & \multicolumn{2}{|c|}{$3.6(2.4 / 5.4)$} \\
\hline $\mathrm{H}_{\mathrm{G} 2 \text {-group }}$ & $6.3(2.3$ & \multicolumn{2}{|c|}{$3.1(0.6 / 4.4)$} \\
\hline G3 (teacher-centered) & $5.5(2.5 / 8.8)$ & $12.1(9.5 / 13.5)$ & $8.9(5.8 / 1.0)$ \\
\hline $\mathrm{R}_{\mathrm{G} 3}$-group & $3.9(2$. & \multicolumn{2}{|c|}{$1.4(1.3 / 4.0)$} \\
\hline $\mathrm{H}_{\mathrm{G} 3}$-group & $5.9(1$. & \multicolumn{2}{|c|}{$2.2(0.8 / 3.6)$} \\
\hline
\end{tabular}

Grouped Median and 25/75th Percentile

* in the three instruction groups in the pre- $\left(\mathrm{T}_{1}\right)$, post- $(\mathrm{T} 2)$ and retention-test $\left(\mathrm{T}_{3}\right)$

* of actual- and persistent learning success in $\mathrm{R}$ - and H-groups in the respective treatments 